\title{
O CORPO NA CONSTITUIÇÃO DO PSÍQUICO
}

\author{
Amanda Fonseca Rodrigues
}

Ao nascer precisamos de alguém que assegure o bem-estar e a sobrevivência do nosso próprio corpo, enquanto dispomos de tempo para crescer e amadurecer. A primeira forma de comunicação que permite esse encontro tão fundamental para a dupla mãe-bebê ocorre através das experiências corpo a corpo. Desse modo, o corpo constitui não só nossa primeira forma de expressão como também o meio através do qual entramos em contato com o mundo. Esse trabalho pretende, portanto, estudar a influência das experiências do corpo naquilo que nos tornamos.

\section{BANCA:}

Monah Winograd (Orientadora)

Ivanise de Azevedo Fontes

Sara Angela Kislanov

Data da defesa: 28/04/2010 